\title{
Efficency of inoculating the green algae Chlorella and Scenedesmus to prevent cyanobacteria growing in Nile tilapia culture
}

\author{
Aida M. Dawah \\ Central Lab.for Aquacult. Research Abbassa, Agricultural Research Center Egypt \\ Email:aidadawah@yahoo.com
}

\begin{abstract}
The purpose of this study was seeding or inoculating the Chlorella elliposoidea (Gerneck) + Scenedesmus bijuga (Turpin) as green algae at the beginning of the production season (or before the preferable time of cyanobacteria growing) to propagate and prevent the growth of harmful cyanobacteria in the Nile tilapia culture via glass aquaria.

Indoor experiment was carried out in natural light using 12 glass aquaria as four groups (3 replicates each). Ten Nile tilapia fingerlings were stocked (Oreochromis niloticus) in each aquarium.

The cyanobacteria were not appeared in the fish aquaria which were seeded or inoculated with Chlorella + Scenedesmus $20 \times 10^{3}$ cells ml $^{-1}\left(\mathrm{~T}_{3}\right)$ at day 5 and 10. The cyanobacterial count was lower in the second treatment $\left(T_{2}\right)$. Significant differences were observed between the cyanobacterial count on day 5 and 10 in the control aquaria and those inoculated with Chlorella + Scenedesmus sp. $(\mathrm{p}<$ 0.05). Higher counts of green algae were observed in aquaria inoculated with the highest dose of Chlorella + Scenedesmus sp. $\left(\mathrm{T}_{3}\right)$. Generally, the green algal count in control aquaria was the lowest, followed by those treated with $10 \times 10^{3}$ cells $\mathrm{ml}^{-1}$ Chlorella + Scenedesmus sp. $\left(\mathrm{T}_{1}\right)$. No significant differences were observed in the green algae and cyanobacteria counts on day 5 and 10 between $\mathrm{T}_{2}$ and $\mathrm{T}_{3}(\mathrm{P}<0.05)$.

The present experiment showed that the presence of Chlorella + Scenedesmus sp. is sufficient to control the growth of cyanobacteria for 10 days period in the Nile tilapia culture.
\end{abstract}

Key words: Efficiency, Cyanobacteria, Chlorella and Scenedesmus, Tilapia

\section{INTRODUCTION}

Commercial fish production ponds are usually operated as "static" systems, with little or no water going in or out. Food, as well as fertilizers are added to almost all ponds, and represent the major source of nutrients in fish ponds. Fortunately, uneaten feed and fish wastes are usually biologically degraded and reused by certain pond organisms. A large portion of these nutrients is chemically or biologically transformed and then released into the water and taken up by the phytoplankton bloom. In a healthy and balanced aquatic 
ecosystem, algae are an important component of the natural plankton population (White et al., 2005).

Chlorella and Scenedesmus sp. are green algae with high chlorophyll content. Tendencia and Dela Pena (2003) reported that Chlorella sp. inhibits the growth of luminous bacteria after $48 \mathrm{~h}$, although this was observed using $500 \mathrm{ml}$ flasks. Corre et al., (2000) and Lio-Po et al., (2002) reported that Chlorella density in ponds using green algae ranged from $10^{5}$ to $10^{6}$ cells $\mathrm{ml}^{-1}$. These micro-algae are found in pond water and could enhance upon exposure to sunlight. It is possible that these micro-algae could have antibacterial activity against some Gram negative bacteria (Lio-Po et al., 2002).

Cyanobacteria (blue-green algae) are a diverse group of photosynthetic, prokaryotic organisms found in fresh water and marine environments (Schoof and Packer, 1987). Their cell structure resembles that of Gram negative bacteria, but as a rule they live photoautotrophically.

In shrimp ponds, rearing water containing Chlorella is considered ideal for disease prevention and it could inhibit growth of pathogenic bacteria isolated from diseased shrimp (Vibrio harveyi, V. parahaemolyticus and $V$. penaeidida) (Direkbusarakom et al., 1997).

The purpose of the present study was to prevent the harmful algal growth of cyanobacteria by inoculating or seeding the Chlorella elliposoidea (Gerneck) + Scenedesmus bijuga (Turpin) as green algae at the beginning of the production season (or before the preferable time of cyanobacteria growing) in the Nile tilapia culture via glass aquaria.

\section{MATERIALS AND METHODS}

The study was conducted at WorldFish Center, Abbassa Sharkia. Chlorella elliposoidea (Gerneck) and Scenedesmus bijuga (Turpin) were isolated from Nile water samples according to Pascher (1915). The microalgae were subcultured in Bold's basal medium (BBM) (Bischoff \& Bold, 1963). The cultures were allowed to grow in the algae culture room at $25{ }^{\circ} \mathrm{C}$ and $14 / 10$ light-dark cycle (5000 lux). Stock cultures of C. elliposoidea \& S. bijuga were prepared in two liters capacity flasks in the laboratory for 5-6 days, then inoculated in carboy cultures at a density of $1 \times 10^{5}$ cells $\mathrm{mL}^{-1}$. The carboy cultures were used as inocula for two different phases of production in indoor and outdoor in glass aquaria. The transfer of the algal cells to fish aquaria was achieved at a density of $5 \times 10^{6}$ cells $\mathrm{mL}^{-1}$, chlorophyll content was $2.9 \mathrm{mg} \mathrm{L}^{-1}$ and dry weight gain was $660 \mathrm{mg} \mathrm{L}^{-1}$.

Indoor experiment was carried out in natural light using 12 glass aquaria as four groups (each aquarium has 100 liters capacity. Three treatments and control groups were carried out in triplicates. Ten Nile tilapia (Oreochromis niloticus) with initial weight each of $30 \pm 3 \mathrm{~g}^{\text {fish }^{-1}}$ were stocked in each aquarium. Experimented fish were fed daily at a rate of 3\% their body weight on commercial formulated feed containing $25 \%$ protein. Aeration was 
supplemented, provided by a regenerative blower and stones submerged at the bottom of each aquarium.

The first 3 aquaria groups were filled with canal water, having a known species composition count of phytoplankton, chlorophyll “a”, "b”, “c” and cphycocyanin content. These aquaria were seeded with green algae $C$. elliposoidea $+S$. bijuga (mixture $1: 1$ ) at 3 initial different densities; $10 \times 10^{3}$ cells $\mathrm{ml}^{-1}\left(\mathrm{~T}_{1}\right), 15 \times 10^{3}$ cells $\mathrm{ml}^{-1}\left(\mathrm{~T}_{2}\right)$ and $20 \times 10^{3}$ cells $\mathrm{ml}^{-1}\left(\mathrm{~T}_{3}\right)$ for $1^{\text {st }}, 2^{\text {nd }}$ and $3^{\text {rd }}$ aquaria groups; respectively. The $4^{\text {th }}$ aquaria group served as a control without addition of green algae $\left(\mathrm{T}_{0}\right)$. Water samples for chemical, physical and biological analyses in all treatments and control were carried out at starting time, 5, 10 days intervals.

The following formula was used to compute for the required volume of stock green algae to be added into the aquaria (Tendencia et al., 2005).

Volume to be added= (desired density-existing density) $\mathrm{x}$ volume of water in aquarium

\section{Density of stock culture}

Chlorophyll a, b, and c contents were determined in water photometrically by using spectrophotometer. Water samples $(100 \mathrm{ml})$ were filtered through a membrane filter (0.45 $\mu \mathrm{m}$ pore size) then extracted with $90 \%$ acetone. Calculation of the chlorophyll a, b, and c was carried out using the equation adopted by APHA (1985). Spectrophotometrically, the C-phycocyanin (CPC) concentration was carried out according to O'Carra and Oh'eocha (1976) and calculated using Beer's law and an extinction coefficient of $7.9 \mathrm{~L} \mathrm{~g} \mathrm{~g}^{-1} \mathrm{~cm}^{-1}$ (Svedberg and Katsurai, 1929):

$C P C \mathrm{gL}^{-1}=A_{625} / 7.9 \mathrm{~L} / \mathrm{g} / \mathrm{cm} \times 1 \mathrm{~cm}$.

Quantitative estimation of phytoplankton was carried out by the technique adopted by APHA (1985) using the sedimentation method. Phytoplankton samples were preserved in Lugol's solution at a ratio of 3 to $7 \mathrm{ml}$ Lugol's solution to one liter sample and concentrated by sedimentation of one liter water sample in volumetric measuring jars for about 2 to 7 days. The surface water was siphoned and the sediment was adjusted to $100 \mathrm{ml}$. From the fixed sample, 1 ml was drown and placed into Sedgwick-Rafter cell, and then it was microscopically examined for counting after identification of phytoplanktonic organisms. The results were expressed as cell counts $\mathrm{ml}^{-1}$. The phytoplankton cells were identified to four divisions as (Chlorophyta), (Cyanobacteria), (Bacillariophyta), and (Euglenophyta). For identification of the algal taxa, Fritsch (1979) and Komarek and Fott (1983) were followed.

Water temperature $\left({ }^{\circ} \mathrm{C}\right)$; and dissolved oxygen $\left(\mathrm{DO}, \mathrm{mgL}^{-1}\right)$ were measured using an oxygen electrode meter. One liter water samples were collected to measure the hydrogen ions $(\mathrm{pH})$ using the ACCUMET $\mathrm{pH}$ meter (model 25), and total ammonia (mg L ${ }^{-1}$ ) using HACH Comparison (1982). Total alkalinity, total hardness and nitrate $\left(\mathrm{NO}_{3}\right)$ were determined according to Boyd \& Tucker (1992). 
One-way ANOVA was used to evaluate the significant difference among treatments and duration. A probability at level of 0.05 or less was considered significant. All statistical analyses were run on the computer, using the SAS program (SAS, 2003).

\section{RESULTS AND DISCUSSION}

Results showed that cyanobacterial count was generally highest in control aquaria (Table 1). The cyanobacterial count in aquaria with Chlorella + Scenedesmus was not appeared and completely inhibited in the fish aquaria which were inoculated with $20 \times 10^{3}$ cells $\mathrm{ml}^{-1}\left(\mathrm{~T}_{3}\right)$ either at day 5 or day 10 . The cyanobacterial count was lower in the second treatment (inoculated with $15 \mathrm{x}$ $10^{3}$ cells $\mathrm{ml}^{-1}$ of green algae). Significant differences were observed in the cyanobacterial count on both day 5 and 10 in the control aquaria and those seeded with Chlorella + Scenedesmus sp. ( $\mathrm{p}<0.05)$.

On the basis of previous work on the control of cyanobacterial blooms using tannic acid treatments might cause oxygen depletion due to algae die off (Dawah et al., 2006a) or Chlorella and Scenedesmus sp. (green algae) treatments, might cause increase in the algal density (Dawah et al., 2006b). The prevention of cyanobacterial growth by inoculating or seeding Chlorella + Scenedesmus sp. (green algae) to propagate and prevent any growth for Cyanobacteria in the Nile tilapia culture was the aim of this study.

Higher green algae counts were observed in aquaria inoculated with high dose of Chlorella + Scenedesmus sp. $\left(20 \times 10^{3}\right.$ cells ml $\left.{ }^{-1}\left(\mathrm{~T}_{3}\right)\right)$. Generally, the green algae count in control aquaria had the lowest count of Chlorella and Scenedesmus sp. No significant differences were observed in the green algae and Cyanobacteria counts on day 5 and 10 in $\mathrm{T}_{2}$ and $\mathrm{T}_{3}(\mathrm{P}<0.05)$ Table. (1).

The aim of the work was based on differences between Chlorella + Scenedesmus and Cyanobacteria (Microcystis, Anabaena and Aphenocapsa) which WorldFish Center, Abbassa, Sharkia suffered from them. Chlorella and Scenedesmus have fast and high growth rates $\left(\mu\right.$ at $\left.25^{\circ} \mathrm{C}=0.7^{\sim} 0.83 \mathrm{~d}^{-1}\right)$, tolerant high temperature up to $35^{\circ} \mathrm{C}$, strongest antimicrobial activity against gramnegative bacteria, (Shi-Li. et al., 2001), fast and very high nutrient uptake capabilities and no aggregation properties but colonization (no blooms). Cyanobacteria are the only prokaryotic organisms carrying out an oxygenevolving photosynthesis (Schopf and Packer, 1987).

To minimize the harmful algal blooms, control of eutrophication or selection of aquaculture sites was suggested as preventive measures (Anderson, 1997), but these strategies were not widely accepted (Sengco et al., 2001). Several chemical methods are employed (Jhingran, 1995), but they are too expensive, ineffective and may have some residual effects in the aquatic organisms (Anderson, 1997). The time to control a harmful algal bloom is before the bloom develops (Webster et al., 1996). 
Results of the present experiment showed that cyanobacteria growth was decreased by increasing the dose of Chlorella + Scenedesmus, and were not detected in fish aquaria with high green algal dose. Aquaria in this study were not covered during sunny days to allow sunlight penetration and encourage growth of micro-algae. Tilapia is herbivorous and filters phytoplankton and it could feed on the seeded Chlorella and Scenedesmus sp. (Turker et al., 2003). Certain freshwater Chlorella and Scenedesmus are cultured as health foods for humans and animals because of the proteins, vitamins, minerals, amino acids and other substances they contain (Halama 1990). Chlorella was added at a density of 50-350 × $10^{4}$ cells per ml starting at day 1 to day 21 to maintain water quality for larval rearing of milkfish (Liao, 1979).

Bacillariophyta was observed in all treatments from day 5 to day 10 increased with increasing of green algal concentration in all treatments and control aquaria, while Euglenophyta was inhibited by increasing inoculates of green algae cells (Table 1).

Table (1): Phytoplankton dynamics (x $10^{3}$ cells $\mathrm{ml}^{-1}$ ) by using different concentration of Chlorella + Scenedesmus sp. in Nile tilapia culture through out the experimental period 10 days)

\begin{tabular}{|c|c|c|c|c|c|c|c|c|c|}
\hline \multirow[b]{2}{*}{ Divisions } & \multirow{2}{*}{$\begin{array}{l}\text { Initial } \\
\text { count }\end{array}$} & \multirow[b]{2}{*}{ Days } & \multirow{2}{*}{$\begin{array}{l}\text { control } \\
\text { count } \\
\end{array}$} & \multicolumn{2}{|c|}{$\begin{array}{c}10 \times 10^{3} \text { cell ml }{ }^{-1} \\
\left(\mathrm{~T}_{1}\right)\end{array}$} & \multicolumn{2}{|c|}{$15 \times 10^{3}$ cell ml ${ }^{-1}\left(\mathrm{~T}_{2}\right)$} & \multicolumn{2}{|c|}{$20 \times 10^{3}$ cell ml $^{-1}\left(\mathrm{~T}_{3}\right)$} \\
\hline & & & & count & \% Inh. & count & $\%$ Inh. & count & \% Inh. \\
\hline & & 5 & $95 \pm 3.5^{\mathrm{Ab}}$ & $8.57 \pm 0.5^{\mathrm{Ba}}$ & 91.0 & $2.1 \pm 0.5^{\mathrm{Ca}}$ & 97.8 & $0.0 \pm 0^{\mathrm{Ca}}$ & 100.0 \\
\hline Cyanobacteria & $0.02 \pm 0.003$ & 10 & $115 \pm 1.73^{\mathrm{Aa}}$ & $2.67 \pm 0.3^{\mathrm{Bb}}$ & 97.7 & $0.733 \pm 0.09^{\mathrm{Bb}}$ & 99.4 & $0.0 \pm 0^{\mathrm{Bb}}$ & 100.0 \\
\hline Chlorophyta & $0.1 \pm 0.02$ & $\begin{array}{l}5 \\
10 \\
\end{array}$ & $\begin{array}{l}11.67 \pm 0.35^{\mathrm{C}} \\
8.63 \pm 0.44^{\mathrm{Db}} \\
\end{array}$ & $\begin{array}{l}512.05 \pm 54.5 \\
\text { Ba } \\
802.67 \pm 47.9 \\
\text { Сa } \\
\end{array}$ & $\begin{array}{l}-4287 \\
-9200 \\
\end{array}$ & $\begin{array}{l}962.67 \pm 37.8^{\mathrm{Ab}} \\
1143.33 \pm 24.0 \\
\mathrm{Ba}\end{array}$ & \begin{tabular}{|l|}
-8149 \\
-13148 \\
\end{tabular} & $\begin{array}{l}\begin{array}{l}1343.33 \pm 35.3 \\
\mathrm{Ab} \\
1546.67 \pm 37.6 \\
\mathrm{Aa}\end{array} \\
\end{array}$ & $\begin{array}{l}-11411.0 \\
-17822.0 \\
\end{array}$ \\
\hline Bacillariophyta & $0.05 \pm 0.003$ & $\begin{array}{c}5 \\
10\end{array}$ & $\begin{array}{l}3.27 \pm 0.2^{\mathrm{Db}} \\
4.27 \pm 0.2^{\mathrm{Da}}\end{array}$ & $\begin{array}{l}7.47 \pm 0.5^{\mathrm{Ca}} \\
8.47 \pm 0.4^{\mathrm{Ca}}\end{array}$ & $\begin{array}{l}-128 \\
-98.4\end{array}$ & $\begin{array}{l}9.53 \pm 0.35^{\mathrm{Ba}} \\
10.6 \pm 0.5^{\mathrm{Ba}}\end{array}$ & $\begin{array}{l}-191.4 \\
-148.2\end{array}$ & $\begin{array}{l}11.57 \pm 0.3^{\mathrm{Ab}} \\
13.23 \pm 0.3^{\mathrm{Aa}}\end{array}$ & $\begin{array}{l}-253.8 \\
-209.8\end{array}$ \\
\hline Euglenophyta & $\begin{array}{l}0.008 \pm 0.00 \\
1\end{array}$ & $\begin{array}{l}5 \\
10 \\
\end{array}$ & $\begin{array}{l}0.667 \pm 0.03^{\mathrm{A}} \\
\mathrm{b} \\
1.24 \pm 0.06^{\mathrm{Aa}} \\
\end{array}$ & $\begin{array}{l}0.262 \pm 0.03^{\mathrm{Ba}} \\
0.14 \pm 0.03^{\mathrm{Bb}}\end{array}$ & $\begin{array}{l}60.7 \\
88.7 \\
\end{array}$ & $\begin{array}{l}0.2 \pm 0.02^{\mathrm{Ba}} \\
0.081 \pm 0.005^{\mathrm{Bb}}\end{array}$ & $\begin{array}{l}70.0 \\
93.5 \\
\end{array}$ & $\begin{array}{l}0.08 \pm 0.005^{\mathrm{Ca}} \\
0.027 \pm 0.003^{\mathrm{Bb}}\end{array}$ & $\begin{array}{l}88.0 \\
97.8 \\
\end{array}$ \\
\hline Total standing crops & $0.178 \pm 0.05$ & $\begin{array}{l}5 \\
10\end{array}$ & $\begin{array}{l}110.6 \pm 3.1^{\mathrm{Bb}} \\
129.14 \pm 1.65 \\
\text { Da }\end{array}$ & $\begin{array}{l}528.35 \pm 253^{\mathrm{B}} \\
\mathrm{a} \\
\mathrm{Ca} \\
\mathrm{C}\end{array}$ & $\begin{array}{l}-377 \\
-530\end{array}$ & \begin{tabular}{|l|}
$974.5 \pm 38^{\mathrm{Ab}}$ \\
$1154.75 \pm 23.8$ \\
$\mathrm{Ba}$
\end{tabular} & $\begin{array}{l}-781.1 \\
-794.2\end{array}$ & $\begin{array}{l}1354.98 \pm 35.2 \\
\text { Ab } \\
1559.96 \pm 37.3 \\
\text { Aa }\end{array}$ & $\begin{array}{l}-1125.1 \\
-1108.0\end{array}$ \\
\hline
\end{tabular}

The C-phycocyanin pigment in $\left(\mathrm{T}_{3}\right)$ as a high dose was zero and completely inhibited at day 5 until day 10 . The c-phycocyanin pigment content showed significant difference between control and all treatments inoculated with Chlorella + Scenedesmus sp. $(\mathrm{p}<0.05)$. 
The results of the pigment content are shown in Fig. (1). The chlorophyll "a" content in aquaria treated with high dose of Chlorella + Scenedesmus sp. $\left(\mathrm{T}_{3}\right)$ was significantly higher than in the other two treatments and control $(\mathrm{p}<$ 0.05). The chlorophyll "b" content was increased by increasing the dose of Chlorella + Scenedesmus sp. as $\mathrm{T}_{3}>\mathrm{T}_{2}>\mathrm{T}_{1}$. The chlorophyll "b" contents showed significant differences between control and all treatment $(\mathrm{p}<0.05)$.
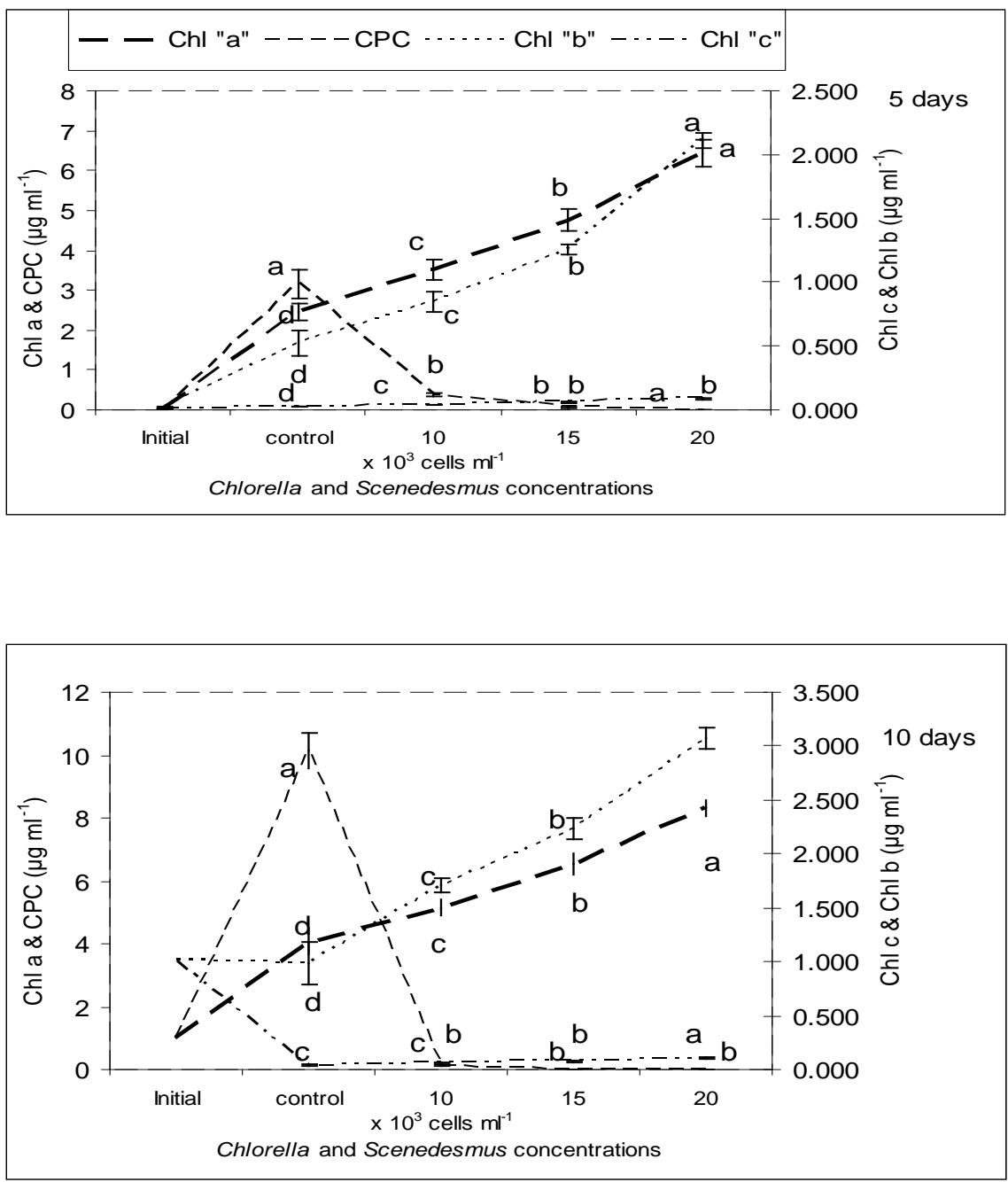

Fig (1): Pigments contents $\left(\mu g \mathrm{ml}^{-1}\right)$ by using different concentration of Chlorella + Scenedesmus sp. in Nile tilapia culture along the period of experiment (10 days) 
A multiple correlation analysis including 9 biological variables was carried out for the experiment (Table 2). The correlation coefficient (r) of the significant relationships $(\mathrm{P}<0.05)$ are only listed. The abundance of green algae showed negative correlation with the abundance of blue green algae $(r=-0.83)$ and Euglenophyta abundance $(\mathrm{r}=-0.82)$. A negative correlation was noticed between chlorophyll " $b$ " content and C-phycocyanin pigment $(r=-0.46)$. The green algal count had high positively correlated with chlorophyll "a” ( $r=0.87)$, chlorophyll “c” ( $\mathrm{r}=0.87)$ and Bacillariophyta abundance $(\mathrm{r}=0.944)$.

Table (2): All over means of Correlation coefficients of biological parameters for prevention of cyanobacteria using different concentration of Chlorella and Scenedesmus at all periods Listed is only the coefficient of the significant correlations $(p<0.05)$

\begin{tabular}{|c|c|c|c|c|c|c|c|c|c|c|}
\hline & & ChlA & ChlB & ChlC & $C P C$ & Cyano & Chloro & Bacill & Eug & Total \\
\hline Chlorophyll "a" & ChlA & 1 & & & & & & & & \\
\hline Chlorophyll "b" & ChlB & 0.9536 & 1 & & & & & & & \\
\hline Chlorophyll "c" & ChlC & 0.9019 & 0.9521 & 1 & & & & & & \\
\hline C-phycocyanin & $C P C$ & -0.406 & -0.457 & -0.507 & 1 & & & & & \\
\hline Cyanobacteria & Cyano & -0.606 & -0.613 & -0.645 & 0.898 & 1 & & & & \\
\hline Chlorophyta & Chloro & 0.8742 & 0.8705 & 0.874 & -0.705 & -0.83 & 1 & & & \\
\hline Bacillariophyta & Bacill & 0.8785 & 0.876 & 0.892 & -0.685 & -0.85 & 0.944 & 1 & & \\
\hline Euglenophyta & Eug & : -0.594 & -0.616 & -0.642 & 0.957 & 0.948 & -0.82 & -0.82 & 1 & \\
\hline tal standing crops & Total & I 0.8841 & 0.8796 & 0.88 & -0.677 & -0.81 & 0.999 & 0.938 & -0.79 & 1 \\
\hline
\end{tabular}

All over means of chosen chemical parameters of water and total gain of Nile tilapia fish at the end of the experiment are shown in Table (3). Results showed no significant difference $(\mathrm{P}<0.05)$ in temperature and nitrate-nitrogen contents of the water in comparison to the control at day 5 . The total alkalinity and ammonia-nitrogen content of the water were significantly higher $(\mathrm{P}<0.05)$ in $T_{3}$ than other treatments and control. The total gain of Nile tilapia in $T_{3}$ was the highest and significantly different $(\mathrm{P}<0.05)$. This is means that fish fed on the green algae Chlorella + Scenedesmus sp. as natural food whereas the lowest value was in control group at the end of experiment.

A number of problems are associated with dense algal blooms. In waters that have a low or moderate buffering capacity (alkalinity), dense blooms create wide fluctuations in $\mathrm{pH}$ during the day. Occasionally, phytoplankton populations cause $\mathrm{pH}$ to reach afternoon values of 10 or above, which depress fish growth and health. Algal die-off can result in high ammonia concentrations that can affect fish appetites and growth rates for extended periods. This can result in reduction of the growing season for fish producers each time an algal bloom dies back in a pond (Brunson et al., (2003). 
Table (3): Water quality parameters and total fish gain by using different concentrations of Chlorella + Scenedesmus in Nile tilapia culture along the experimental period (10 days)

\begin{tabular}{|c|c|c|c|c|c|c|}
\hline Parameters & Initial & Days & control & $\begin{array}{c}10 \times 10^{3} \text { cell } \mathrm{ml}^{-1} \\
\left(\mathrm{~T}_{1}\right)\end{array}$ & $\begin{array}{c}15 \times 10^{3} \text { cell } \mathrm{ml}^{-1} \\
\left(\mathrm{~T}_{2}\right)\end{array}$ & $\begin{array}{c}20 \times 10^{3} \text { cell } \mathrm{ml}^{-1} \\
\left(\mathrm{~T}_{3}\right)\end{array}$ \\
\hline $\begin{array}{l}\text { Dissolved oxygen } \\
\left(\mathrm{mg} \mathrm{L}^{-1}\right)\end{array}$ & $6.5 \pm 0.1$ & $\begin{array}{c}5 \\
10 \\
\end{array}$ & $\begin{array}{l}7.83 \pm 0.14^{\mathrm{A}} \\
8.0 \pm 0.18^{\mathrm{B}}\end{array}$ & $\begin{array}{c}8.06 \pm 0.1^{\mathrm{A}} \\
8.23 \pm 0.06^{\mathrm{A}} \\
\end{array}$ & $\begin{array}{c}7.8 \pm 0.12^{\mathrm{A}} \\
8.35 \pm 0.03^{\mathrm{A}} \\
\end{array}$ & $\begin{array}{l}7.97 \pm 0.2^{\mathrm{A}} \\
8.5 \pm 0.09^{\mathrm{A}} \\
\end{array}$ \\
\hline Temperature $\left({ }^{\circ} \mathrm{C}\right)$ & $20.5 \pm 0.12$ & $\begin{array}{c}5 \\
10 \\
\end{array}$ & $\begin{array}{c}21.8 \pm 0.17^{\mathrm{A}} \\
21.4 \pm 0.15^{\mathrm{AB}}\end{array}$ & $\begin{array}{l}22.2 \pm 0.2^{\mathrm{A}} \\
22 \pm 0.09^{\mathrm{A}} \\
\end{array}$ & $\begin{array}{c}22.5 \pm 0.35^{\mathrm{A}} \\
21.2 \pm 0.3^{\mathrm{B}} \\
\end{array}$ & $\begin{array}{c}22.1 \pm 0.26^{\mathrm{A}} \\
21.6 \pm 0.23^{\mathrm{AB}}\end{array}$ \\
\hline $\mathrm{pH}$ & $8.2 \pm 0.03$ & $\begin{array}{c}5 \\
10 \\
\end{array}$ & $\begin{array}{l}8.7 \pm 0.04^{\mathrm{A}} \\
8.7 \pm 0.07^{\mathrm{B}} \\
\end{array}$ & $\begin{array}{l}8.6 \pm 0.09^{\mathrm{AB}} \\
8.6 \pm 0.06^{\mathrm{B}} \\
\end{array}$ & $\begin{array}{l}9.02 \pm 0.25^{\mathrm{A}} \\
9.0 \pm 0.06^{\mathrm{A}} \\
\end{array}$ & $\begin{array}{c}8.4 \pm 0.09^{\mathrm{B}} \\
8.7 \pm 0.15^{\mathrm{AB}} \\
\end{array}$ \\
\hline Ammonia $\left(\mathrm{mgL}^{-1}\right)$ & $0.04 \pm 0.00 €$ & $\begin{array}{c}5 \\
10 \\
\end{array}$ & $\begin{array}{l}0.08 \pm 0.009^{\mathrm{D}} \\
0.13 \pm 0.018^{\mathrm{D}}\end{array}$ & $\begin{array}{c}0.113 \pm 0.007^{\mathrm{C}} \\
0.16 \pm 0.02^{\mathrm{BC}} \\
\end{array}$ & $\begin{array}{c}0.21 \pm 0.01^{\mathrm{B}} \\
0.21 \pm 0.02^{\mathrm{AB}}\end{array}$ & $\begin{array}{c}0.15 \pm 0.007^{\mathrm{A}} \\
0.26 \pm 0.02^{\mathrm{A}}\end{array}$ \\
\hline T. alkalinity $\left(\mathrm{mg} \mathrm{L}^{-1}\right)$ & $254 \pm 2.6$ & $\begin{array}{c}5 \\
10 \\
\end{array}$ & $\begin{array}{c}216.3 \pm 0.88^{\mathrm{C}} \\
238.7 \pm 8.1^{\mathrm{A}} \\
\end{array}$ & $\begin{array}{c}246 \pm 3.1^{\mathrm{B}} \\
227.3 \pm 10.3^{\mathrm{A}}\end{array}$ & $\begin{array}{c}254.7 \pm 3.3^{\mathrm{B}} \\
230 \pm 7.5^{\mathrm{A}} \\
\end{array}$ & $\begin{array}{c}273.7 \pm 4.7^{\mathrm{A}} \\
258.3 \pm 13.6^{\mathrm{A}} \\
\end{array}$ \\
\hline T. hardness (mg L ${ }^{-1}$ ) & $220 \pm 3.7$ & $\begin{array}{c}5 \\
10 \\
\end{array}$ & $\begin{array}{l}231.3 \pm 4.7^{\mathrm{A}} \\
208.7 \pm 4.7^{\mathrm{B}} \\
\end{array}$ & $\begin{array}{l}237.7 \pm 2.3^{\mathrm{A}} \\
234.7 \pm 2.9^{\mathrm{A}} \\
\end{array}$ & $\begin{array}{l}207.3 \pm 2.4^{\mathrm{B}} \\
218 \pm 7.6 \mathrm{~A}^{\mathrm{B}} \\
\end{array}$ & $\begin{array}{c}200.3 \pm 0.33^{\mathrm{B}} \\
208.7 \pm 4.4^{\mathrm{B}} \\
\end{array}$ \\
\hline $\mathrm{NO}_{3}\left(\mathrm{mg} \mathrm{L}^{-1}\right)$ & $0.06 \pm 0.03$ & $\begin{array}{c}5 \\
10 \\
\end{array}$ & $\begin{array}{c}0.003 \pm 0.002^{\mathrm{B}} \\
0.0007 \pm 0.0006^{\mathrm{B}}\end{array}$ & $\begin{array}{c}0.002 \pm 0.0009^{\mathrm{B}} \\
0 \pm 0^{\mathrm{B}}\end{array}$ & $\begin{array}{c}0.02 \pm 0.006^{\mathrm{A}} \\
0.0007 \pm 0.0006^{\mathrm{B}}\end{array}$ & $\begin{array}{c}0.007 \pm 0.004^{\mathrm{AB}} \\
0.03 \pm 0.02^{\mathrm{A}}\end{array}$ \\
\hline Available phosphorus & $0.54 \pm 0.04$ & $\begin{array}{c}5 \\
10 \\
\end{array}$ & $\begin{array}{c}0.09 \pm 0.005^{\mathrm{A}} \\
0.13 \pm 0.02^{\mathrm{B}} \\
\end{array}$ & $\begin{array}{c}0.09 \pm 0.02^{\mathrm{A}} \\
0.118 \pm 0.032^{\mathrm{B}}\end{array}$ & $\begin{array}{c}0.13 \pm 0.06^{\mathrm{A}} \\
0.254 \pm 0.06^{\mathrm{A}} \\
\end{array}$ & $\begin{array}{c}0.113 \pm 0.009^{\mathrm{A}} \\
0.13 \pm 0.008^{\mathrm{B}} \\
\end{array}$ \\
\hline \multicolumn{2}{|c|}{ Initial body weight (g/10 fish) } & 10 & $307.7 \pm 9.02^{\mathrm{A}}$ & $260.7 \pm 23.8^{\mathrm{B}}$ & $287 \pm 9^{\mathrm{AB}}$ & $299 \pm 7.6^{\mathrm{AB}}$ \\
\hline \multicolumn{2}{|c|}{ Final body weight (g/10 fish) } & 10 & $321.7 \pm 9.8^{\mathrm{A}}$ & $275.7 \pm 24.06^{\mathrm{A}}$ & $302.7 \pm 7.7^{\mathrm{A}}$ & $315.7 \pm 8.09^{\mathrm{A}}$ \\
\hline Total gain (g/aquarium & & 10 & $14 \pm 1.15^{\mathrm{B}}$ & $15 \pm 0.58^{\mathrm{A}}$ & $15.7 \pm 1.3^{\mathrm{A}}$ & $16.7 \pm 0.88^{\mathrm{A}}$ \\
\hline
\end{tabular}

A, B, C, D. Values-having different script at the same row are significantly $(\mathrm{P}<0.05)$ different

The present experiment showed that the presence of Chlorella + Scenedesmus sp. is sufficient enough to control the growth of cyanobacteria for 10 days period in the Nile tilapia culture.

The presence of Chlorella spp. alone was efficient for controlling the growth of Cyanobacteria but maintaining the algal density of a single kind of microalgae in a simulated environment was labor intensive. Among the problems associated with the use of algal cells as fish feed is that the low digestibility of the algal cells makes the algal biomass unsuitable for rearing fishes. Moreover, mixed diets containing several species of microalgae have been reported to give better results for some organisms (Hu, 1990).

This study has also shown that it is advisable to encourage or allow the growth of more than one green alga, especially Scenedesmus to control Cyanobacteria in Nile tilapia culture.

This study serves as a guide to know the green algal density for controlling Cyanobacteria in Nile tilapia ponds. It also provides a basic information for future research field studies along the same line. 


\section{REFERENCE}

Anderson, D. M. (1997). Bloom dynamics of toxic Alexandrium species in the northeastern U.S. Limnol. Oceanogr. 42(5): 1009-1022.

APHA (American Public Health Association). (1985). Standard Methods for the Examination of Water and Wastewater, $19^{\text {th }}$ ed. American Public Health Association, Washhhington, DC.

Bischoff, H.W. and Bold, H.C. (1963). Phycological studies. IV. Some soil algae from Erchanted rock and related algal species. Univ. Texas. $N$. 6318: 32-36.

Boyd E.C. and Tucker C.S. (1992). Water quality and soil analyses for aquaculture. Alabama Agricultural Experiment Station, Auburn Univ., USA.

Brunson, M.W.; Lutz, C.G. and Durborow R.M., (2003). Algae Blooms in Commercial Fish Production Ponds. Aqua KE Gov. Doc., Jan: 7250110.

Corre VL, R Janeo, CM Caipang \& AT Calpe (2000). Use of probiotics and reservoirs with "green water" and other tips for a successful shrimp culture. Aquac. Asia. 14-18.

Dawah, A.M.; El-Naggar, G. and Meslhy, S. (2006a). Biological Control of the Cyanobacterium Microcystis aeruginosa using Chlorella and Scenedesmus in the Nile Tilapia Cultures. $7^{\text {th }}$ Inter. Symposium on Tilapia in Aquacultute: ISTA 7 Boca del Río, Veracruz, México, September 6-8.

Dawah, A.M.; El-Naggar, G. and Meslhy, S. (2006b). Control of Microcystis aeruginosa using tannic acid. $1^{\text {st }}$ Inter. Envir. Forum. Fac. Sci., Tanta Univ., April 1-3.

Direkbusarakom, S.; Pechmanee, T.; Assavaaree, M. and Danayadol, Y. (1997). Effect of Chlorella on the Growth Of Vibrio Isolated from Diseased Shrimp. In T.W. Flegel and I.H. MacRae (eds.), Diseases in Asian Aquaculture 1ll. Fish Health Section, Asian Fisheries Society, Manila.

Fritsch, F.E. (1979). The structure and reproduction of the Algae. Vikas Publ. House, New Delhi, 791 pp. 
HACH., (1982). Hach Chemical Co., Methods Manual, $10^{\text {th }}$ ed., Hach Chemical Company, Ames, IA,

Halama, K. (1990). Single Cell Protein. IN: Non-conventional Feed Stuffs in the Nutrition of Farm Animals (Editor: Kolman B.). Elsevier, pp 34-49.

Hu, Q. (1990). On the culture of Penaeus penicillatus and P. chinensis in Southern China. In: K. Main and Fulks (Eds.). The culture of coldtorerant shrimp: Proceedings of an Asian - U.S. Workshop on shrimp culture. The Oceanic Institute, Honolulu, Hawaii. pp. 77-91.

Jhingran, V. G. (1995). Fishan and fisheries of India, Hindustan Publishing Corporation of India, Delhi, pp. 23-248.

Jones, A.K. (1988). Algal extracellular product: antimicrobial substance. In L.J. R. Gallon (eds.), Proc. Of the phytochemical Society of Europe, Clarendon Press, Oxford, pp. 257-334.

Komarek, J. and Fott. B.,(1983). Das phytoplankton des Susswassers 7 teil, I. Halfte, Pub. E. Schweizerbartsche verlagbuchhandlung (Nagele U. Obermiller).

Liao, I.C. (1979). On induced spawning and larval rearing of milkfish, Chanos chanos Forskal. Aquaculture, 180: 75-93.

Lio-Po, G.D.; Leano, E.M.; Usero, R.C. and Guanzon Jr., N.G., (2002). Vibrio harveyi and the green water culture of Penaeus monodon. In: Inui, Y., Cruz-Lacierda, E.R. (Eds.), Disease Control in Fish and Shrimp Aquaclture in Southest Asia. Diagnosis and Husbandry Techniques. SEAFDEC AQD, Iloilo, Philippines, pp. 172-180.

O'Carra P. and Oh'eocha, C. (1976). Algal biliproteins and phycobilins.In: (Ed. T.W. Goodwin), chemistry and biochemistry of plant pigments. Vol. 1, pp. 328-376, Academic press, London, New York -San Francisco.

Pascher, A. (1915). Bd. S. Chlorophyceae - Gustav Fisher. Verlag, Jena.

SAS Institute (2003). SAS/STAT Guide for Personal Computers, $6^{\text {th }}$ ed. Cary, NC.

Schopf, J. W. and Packer, B. M. (1987). Early Archean (3.3 Billion to 3.5 Billion-Year-Old) Microfossils from Warrawoona Group, Australia, Science, 237: 70-73. 
Sengco, M.R.; Li, A.; Tugend, K.; Kulis, D.; Anderson, D.M.(2001). Removal of red and brown tide cells using clay locculation. 1. Laboratory culture experiments with Gymnodinium breve and Aureococcus anophagefferens. Mar. Ecol. Prog. Ser. 210: 41-53.

Shi-Li, C.; Chun-Yao, C.; Woan_Ru,L.; Rung H. and Liang-Ping L. (2001). Hemagglutination, antibiotic activity and identification of Chlorella spp. Isolates. $6^{\text {th }}$ Asian Fisheries Forum Book of Abstracts Unit-A, Mayaman Townhomes 25 Mayaman street Up Village Quezon City Philippines Asian Fisheries Society.

Svedberg J. and Katsurai, J., (1929). The molecular weight of phycocyanin and of phycoerythrin from Porphyra tenera and of phycocyanin from Aphanizomenon flos-aquae. J. am. Chem. Soc., 51: 3573-3583.

Tendencia, E.A.; dela Pena, M.R.; (2003). Investigation on some some components of the greenwater culture system which makes it effective in the initial control of luminous bacteria. Aquaculture 218:115-119.

Tendencia, E.A.; dela Pena, M.R. and Choresca Jr., C.H. (2005). Efficiency of Chlorella sp. and Tilapia hornorum in controlling the growth of luminous bacteria in a simulated shrimp culture environment. Aquaculture, 249: 55-62.

Turker, H. Eversole, A.G. and Brune, D.E.(2003). Filtration of green algae and cyanobacteria by Nile tilapia, Oreochromis niloticus, in the Partitioned Aquaculture System, Aquaculture, 215 (1-4) : 93-101.

Webster I., Bormans, M., Jones, G. J. Oliver, R., Sherman, B. (1996). Control Strategies for Cyanobacterial Blooms in Weir Pools. NRMS Project M3116 Final Report, 46 pp.

White S.H., Duivenvoorden L.J. and Fabbro L.D. (2005). Impacts of a Toxic Microcystis Bloom on the Macroinvertebrate Fauna of Lake Elphinstone, Central Queensland, Australia Hydrobiologia., 548(1):117. 